\title{
NEW INITIATIVE TO EDUCATE THE “POSTPRESS: BINDING, FINISHING AND MAILING" AS OBLIGATORY COURSE-UNIT AT ÓBUDA UNIVERSITY
}

\author{
Piroska Prokai (D), Csaba Horvath \\ Óbuda University, Institute of Media Technology and \\ Light Industry Engineering, Budapest, Hungary
}

\begin{abstract}
This online course-unit (lecturing at the Obuda University) assembled by the authors, is a primer that serves a dual role for today's students of graphic communication. The course is an introduction to the process of post-press technologies and the different kind of bookbinding technologies, what is solid base for any printer professional that wants or needs to learn how does is works the end of in the printing house. The knowledge based on our revised manuscripts of well-known Hungarian printing industry professionals as Lajos Papp (Horvath et al, n.d.) and Gyorgy Toth (Prokai et al, n.d.). The curriculum contains presentations, videos, tests and tasks for home work. The course is presented during one semester. The credit point value of the course is 2. The students are following the lectures online week by week. They need to pass six tests and complete six home works assignments to monitor their progress. This course is designed for the students of Obuda University.
\end{abstract}

Key words: postpress, book-binding education, finishing technologies, e-learning

\section{INTRODUCTION}

This English language online course-unit (lecturing at the Obuda University) assembled by the author, is a primer that serves a dual role for today's students of graphic communication. The main task of the students in this course is to design and virtually create their own future efficient and sustainable enterprise in graphic communication using the binding, finishing and mailing tool box while also considering the associated social responsibility (CSR) aspects.

This course is designed for the students of Obuda University, who are studying the undergraduate academic course of "Light industry engineering" and their specification is the graphic communication. The fulfilment of this course in English language is criteria to get their degrees.

\section{UNIVERSITY, FACULTY - THE PLACE OF EDUCATION}

Obuda University is a dynamic and thriving institution located in Budapest, heart of Hungary, heart of Europe. For 132 years of existence, the educational excellence has remained paramount. The history of our institution is spanning over three centuries. Obuda University was established as of 1 January 2010, as a legal successor of Budapest Tech - and its legal predecessors, namely Donat Banki Technical College, Kalman Kando Technical College, and the Technical College of Light Industry. The fundamental mission of the University is to serve science and the future by transferring and developing knowledge at high standards and by research and innovation. The high level education is going on in various faculties and centres. These faculties are found in the parts of Budapest and Szekesfehervar. Obuda University has six faculties:

- Banki Donat Faculty of Mechanical and Safety Engineering,

- Kando Kalman Faculty of Electrical Engineering,

- Keleti Karoly Faculty of Economics,

- John von Neumann Faculty of Information Technology,

- Rejto Sandor Faculty of Light Industry and Environmental Engineering,

- Alba Regia Faculty of Engineering (Szekesfehervar).

Obuda University constantly builds and develops a competitive institution of higher education meeting the criteria and regulations of the European Higher Education Area (Figure 1). 


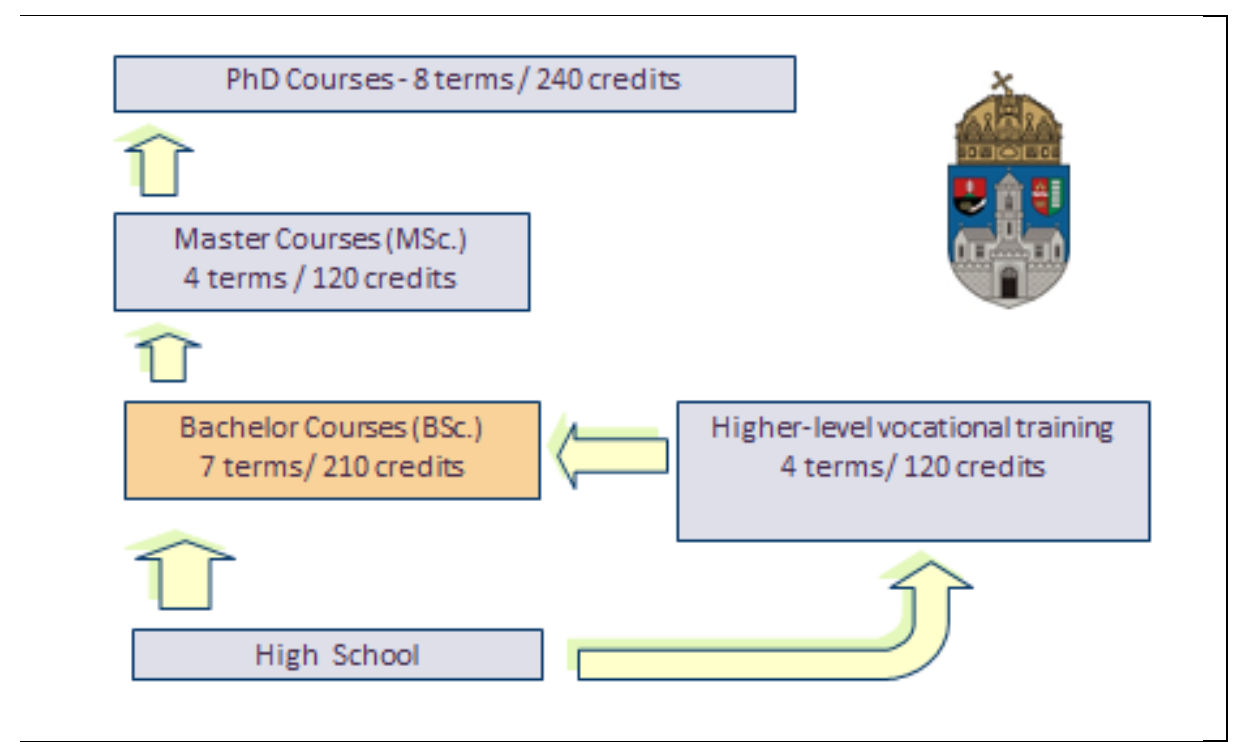

Figure 1: Education system of Obuda University

Rejtő Sándor Faculty of Light Industry and Environmental Engineering offers three BSc programs: Light Industry Engineering, Industrial Design Engineering, Environmental Engineering, and a MSc program in Light Industry Engineering.

- The bachelor's program in Light Industry Engineering prepares students for the control and supervision of manufacturing processes related to their specialisation. After completing the fundamental courses in engineering, with basic technical and engineering skills they can choose from the following specialisations: Print media, packaging design and technologies; Industry system development and quality management.

- Engineers, with a BSc degree in Industrial Design Engineering will be able to initiate, compile and implement projects, to carry out analyses using relevant design methods and to professionally justify the implemented work procedures. They will have competence in comprehensive product design, taking into consideration aesthetic, usability, market, safety, and implementation aspects, as well as historic, cultural, social, economic, industrial and natural environmental factors related to industrial design and product development. Specialisations: Product Design and Product Management.

- BSc Environmental Engineers will possess the necessary up-to-date vocational and technological skills needed to reduce and prevent environmental damage and pollution. They are trained to be capable of making environmental studies. We offer the Light Industry specialisation.

- Those who earned the BSc degree can continue their studies on the Light Industry Engineering MSc program. The training is organised in cooperation with the Faculty of Wood Sciences of University of West Hungary. Graduates of the BSc program may also continue their studies in the Engineering Teacher Master program in cooperation with Trefort Ágoston Centre for Engineering Education.

\section{CRITERIA SUBJECT}

By the regulation of Obuda University the undergraduate students have to cover four credits from the criteria subjects to get their degrees. An example can be seen on the Table 1 . The criteria lectures units are optional presented in English or German languages.

This subject is prepared and proposed to the student who had chosen the "Print media, Packaging design and technologies" specialization instead of the Hungarian language blended version. The Obuda University's future aim is to educate bilingual engineers, who can speak fluently in English beside their mother language. It is the reason we created this subject in English. Our faculty's dean motivates the teacher staff to create more e-learning subjects as an obligatory. Our project is the pilot one. 
Table 1: Curriculum of Light Industry Engineering course (BSc.) for full time students

\begin{tabular}{|c|l|c|}
\hline No. & Main fields of study & Credit [Pts] \\
\hline 1 & Natural Science Fundamentals & 41 \\
\hline 2 & Economics and Human Studies & 20 \\
\hline 3 & Technical Fundamentals & 65 \\
\hline 4 & Specializations & \\
\hline & $\square \quad \begin{array}{l}\text { Print media, Packaging design and technologies } \\
\text { Industrial system development and quality } \\
\text { management }\end{array}$ & \\
\hline 5 & Optional course-units & 6 \\
\hline 6 & Criteria Subjects (English or German) - optional & 4 \\
\hline 7 & Thesis & 15 \\
\hline Sum: & $\quad$ & 210 \\
\hline
\end{tabular}

\section{E-LEARNING COURSE UNIT OF "POSTPRESS: BINDING, FINISHING AND MAILING"}

The knowledge base of the course is founded on the new American and German. It is an English language online course unit, managed by the E-learning system of Obuda University. This optional criteria subject is educated by credit-based ( 2 credit points). The length of the programme is one semester (14 weeks), opened for all undergraduate students (not only for OE students).

\subsection{Why the bookbinding?}

The graphic arts industry has experienced tremendous change in the last quarter century. While the prepress and press areas have received the majority of the attention from the trade media, the bindery and finishing areas have gone largely unnoticed ... until now. The product variety of the finishing industry is illustrated in the overview shown in Figure No.2. In this subject we focus the bookbinding operation.

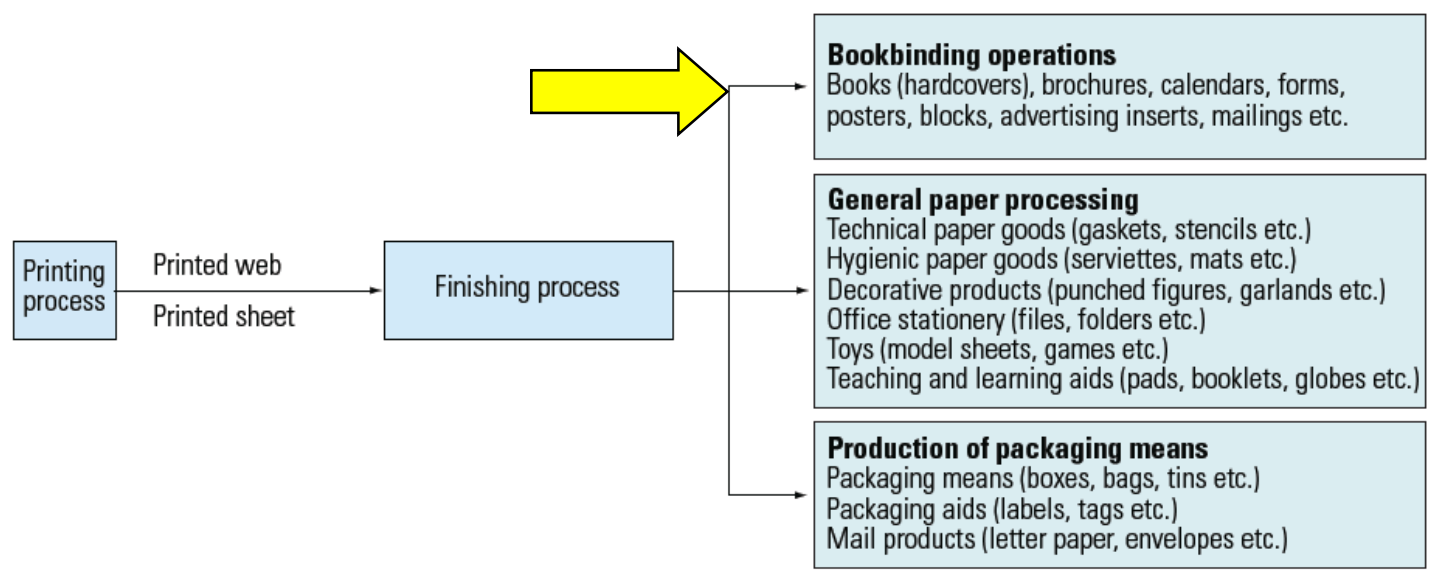

Figure 2: Print finishing products (Kipphan, 2001)

The course is a primer that serves a dual role for today's students of graphic communication. It's an introduction to the world of binding, finishing and mail preparation. It's also a first pass - a necessary first coat - that will provide a solid base for any printer who wants or needs to know more about the postpress technologies, about the final word of printing. The presentation has been recorded with voice-over with help of Camtasia software. 
The curriculum contains presentations, videos, tests and tasks for home work. The course is presented during one semester. The credit point value of the course is 2.The students are following the lectures online week by week. They need to pass six tests and complete six homework assignments to monitor their progress. They finish the course unit with a closing test. The description, brief curriculum and the requirements are on the Table 2 .

Table 2: Printing technologies No.3 (Binding, finishing and mailing) - brief curriculum and requirements

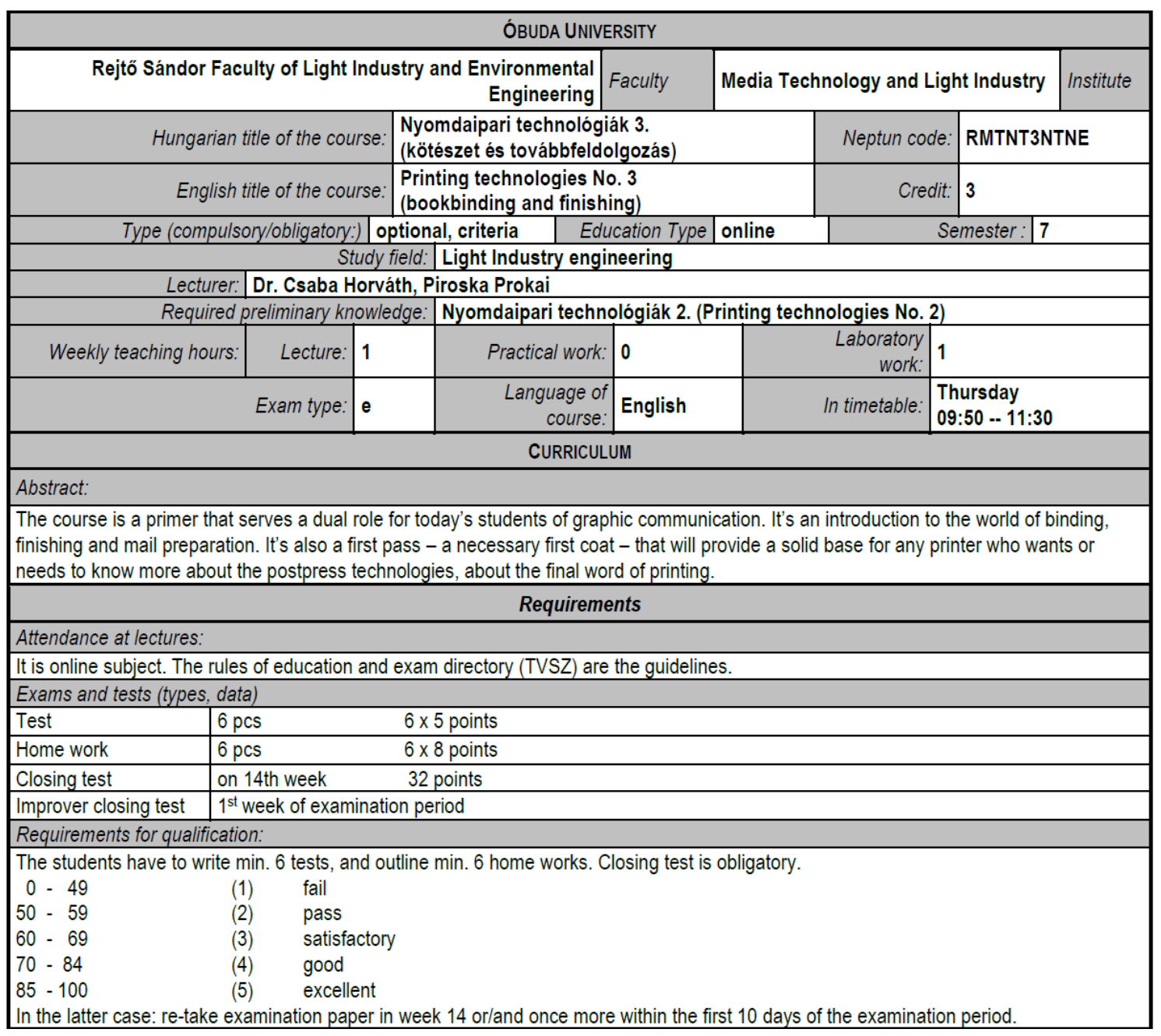

The detailed curriculum can be followed on the Table 3 and Table 4. All the files (marked $\mathbf{a}$ ) are loaded to the platform of E-learning system. The students load up their home works and closing test to this platform. The six tests are passed by the students on the platform of E-learning system (https://elearning.uni-obuda.hu/). 


\begin{tabular}{|c|c|c|}
\hline Lecture & Subject & Test/Homework \\
\hline No. 1 & $\begin{array}{l}\text { Introduction (Presentation No. 1) } \\
\text { The course "Bookbinding and finishing" is an online course. } \\
\text { The education is organized by the E-learning system of } \\
\text { Óbuda University. } \\
\text { The tests, the home works, the practices and the valuating } \\
\text { are managed through the E-learning system. } \\
\text { Lecturer: Dr. Csaba Horvath, Piroska Prokai } \\
\text { - Teachers' introducing (video) } \\
\text { - } \quad \text { Sample of Europass CV (pdf) } \\
\text { - Sources to learn, required } \\
\text { - Binding, Finishing and mailing: The Final Word } \\
\text { - } \quad \text { Handbook of Print Media (Kipphan, 2001) } \\
\text { - Source to learn, proposed } \\
\text { - Sappi } 06 \text { The Standard (Sappi North America, 2012) } \\
\text { - Bookbinding (Morlok et al, 2018) }\end{array}$ & $\begin{array}{l}\text { - Students CV'S } \\
\text { Students are needed to create } \\
\text { and submit their CV's in English. } \\
\text { Format: Europass }\end{array}$ \\
\hline No. 2 & $\begin{array}{l}\text { Cutting and Die-cutting } \\
\text { - } \quad \text { Presentation No.2 } \\
\text { - } \quad \text { Cutting: step by step (educational video) } \\
\text { - } \quad \text { PERFECTA } 132 \text { TS High-speed Cutter (video) } \\
\text { - } \quad \text { MM Granit three-knife trimmer (video) } \\
\text { - } \quad \text { Bobst SPrintera } 106 \text { PER Die cutter (video) }\end{array}$ & - $\quad$ Test No.1 \\
\hline No. 3 & $\begin{array}{l}\text { Folding } \\
\text { - } \quad \text { Presentation No.3 } \\
\text { - } \quad \text { Buckle fold principles (animation video) } \\
\text { - } \quad \text { Knife fold principle (animation video) } \\
\text { - Operating of MBO M80-K folder (video) } \\
\text { - Herzog+Heynemann Pharma Line folder (video) }\end{array}$ & - $\quad$ Test No.2 \\
\hline No. 4 & $\begin{array}{l}\text { Assembling Blocks, Saddle Stitching, Sewing } \\
\text { - } \quad \text { Presentation No.4 } \\
\text { - } \quad \text { Kolbus book block production (video) } \\
\text { - Saddle stitcher Primera (video) } \\
\text { - MM Ventura sewing machine (demo video) } \\
\text { - Meccanotecnica sewing (video) }\end{array}$ & - $\quad$ Test No.3 \\
\hline No. 5 & $\begin{array}{l}\text { Perfect Binding } \\
\text { - } \quad \text { Presentation No.5 } \\
\text { - } \text { MM Alegro perfect binder (video) } \\
\text { - Kolbus perfect binder (video) } \\
\text { - } \quad \text { Adhesive binding: tips and tricks (pdf) }\end{array}$ & - $\quad$ Test No.4 \\
\hline No. 6 & $\begin{array}{l}\text { Case Making and Book Cover Producing } \\
\text { - Presentation No.6 } \\
\text { - } M M \text { Collibri backgluing (video) } \\
\text { - MM Diamant Bookline (video) } \\
\text { - MM Ribbon inserting (video) } \\
\text { - Hardcover vs. Paperback: Which option is better? (pdf) } \\
\text { - Hard cover case maker (video) }\end{array}$ & - $\quad$ Test No.5 \\
\hline No. 7 & $\begin{array}{l}\text { Finishing Short Print Runs (Digital Finishing) } \\
\text { - Presentation No.6 } \\
\text { - } \quad \text { Photobook technology (video) } \\
\text { - Paperfox equipment (videos) } \\
\text { - } \quad \text { Digital finishing (pdf) }\end{array}$ & - $\quad$ Test No.6 \\
\hline
\end{tabular}


Table 4: Printing technologies No.3 (Bookbinding and finishing) - the detailed curriculum of Lab practice No. 8 - 14

\begin{tabular}{|c|c|c|}
\hline Practices & Subject & Test / Homework \\
\hline $\begin{array}{l}\text { No. } \\
8 \text { - } 9\end{array}$ & $\begin{array}{l}\text { Design and making of name card and wall calendar } \\
\text { - Presentation No.8-9 } \\
\text { - } \text { - } \text { A pracking regulations in the printing lab (pdf) } \\
\text { - } \text { A practical guide making name card (video) } \\
\text { calendar (video) } \\
\text { - } \text { Blazon of Óbuda University (jpeg) } \\
\text { - Sample for name card design (pdf) } \\
\text { - Graphic Design (pdf) (Prokai et al, n.d.) } \\
\text { - Design of calendars (URL) }\end{array}$ & $\begin{array}{l}\text { Homework No.1-2. } \\
\text { First the student design their } \\
\text { name card and personalised } \\
\text { wall calendar for next year. } \\
\text { Than they make and finished } \\
\text { them alone following the video } \\
\text { intentions in the printing lab. } \\
\text { (Lab supervisor supports them.) }\end{array}$ \\
\hline No. 10 & $\begin{array}{l}\text { Art of Marbling } \\
\text { - } \quad \text { Presentation No.10 } \\
\text { - How to paint on Water for Paper Marbling? (video) }\end{array}$ & $\begin{array}{l}\text { Tomework N.3 } \\
\text { patterned paper sheets with } \\
\text { marbling art. They can use them } \\
\text { for endpaper or cover of their } \\
\text { handmade book. } \\
\text { (Lab supervisor supports them.) }\end{array}$ \\
\hline $\begin{array}{c}\text { No. } \\
11-12\end{array}$ & $\begin{array}{l}\text { Assembling a hard-covered book by handmade technology } \\
\text { - Presentation No.11-12 } \\
\text { - Handmade bookbinding tutorial (video) }\end{array}$ & $\begin{array}{l}\text { Homework No.5 } \\
\text { Students assemble by hand a } \\
\text { hardcover, sawn book step by } \\
\text { step from recycled paper using } \\
\text { their marbled paper. } \\
\text { (Lab supervisor supports them.) }\end{array}$ \\
\hline No. 13 & $\begin{array}{l}\text { Visit in a bookbinder company } \\
\text { - Presentation No.13 (Intention for the visit.) } \\
\text { - Introducing the company (video) }\end{array}$ & $\begin{array}{l}\text { Homework No.6 } \\
\text { Students create a report about } \\
\text { the company visit focusing the } \\
\text { things what they liked. } \\
\text { The company visit guided } \\
\text { by teachers. }\end{array}$ \\
\hline No. 14 & \multicolumn{2}{|l|}{ Closing test (45 minutes) } \\
\hline
\end{tabular}

\section{CONCLUSION}

The "Printing technologies No.3 (Binding, finishing and mailing)" course unit was launched in fall semester of 2018, two month ago. That's way we haven't got enough experiences about it. We only hope this course-unit will be a successful and popular program very soon, supported the marketing of the paper-based communication.

The Obuda University is so open to collaborate with other universities:

- $\quad$ to split the education of 'Lean and green printing',

- to develop this course-unit together,

- students from other universities are welcome.

In this case you should contact to the author to get login, etc.

\section{ACKNOLEDGEMENTS}

We say a special thanks to Mr. Tibor Sándor - who is the managing director of Müller-martini Magyarország $\mathrm{Kft}$. for his help. He supported us with videos and a lot of technical material to make the presentations. 


\section{REFERENCES}

[1] Horvath, C., Papp, I.: "Nagyüzemi könyvgyártás", (book under preparation)

[2] Kipphan, H.: "Handbook of Print Media”, (Springer Verlag, Heideleberg, 2001.), page 1208.

[3] Morlok, F., Waszelewski, M., Wright, C.: "Bookbinding: A Comprehensive Guide to Folding, Sewing, \& Binding", (Princeton Architectural Press, Princeton, 2018.), page 420.

[4] Prokai, P., Tóth, G.: "Kötészeti technológiák", (book under preparation)

[5] Sappi North America: "The Standard 06 - Bindery Techniques", (Sappi North America, Boston, 2012.), page 88.

[6] Tedesco, T. J., Clossey D., Hershey, J.: "Binding, Finishing and Mailing: The Final World", (PIA/GATFPress, Pittsburgh, 2005.), page 388.

(C) 2018 Authors. Published by the University of Novi Sad, Faculty of Technical Sciences, Department of Graphic Engineering and Design. This article is an open access article distributed under the terms and conditions of the Creative Commons Attribution license 3.0 Serbia (http://creativecommons.org/licenses/by/3.0/rs/). 